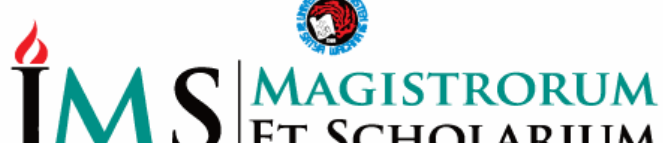 \\ JMS Er schourdum
}

P-ISSN: 2722-9270

ejournal.uksw.edu/jms

\section{Meningkatkan Konsentrasi Belajar Peserta Didik dengan Bimbingan Klasikal Metode Cooperative Learning Tipe Jigsaw}

Olivia Fridaram

Elisabet Istharini

Petra Gian Cinta Cicilia

Asih Nuryani

Doddy Hendro Wibowo*

Fakultas Psikologi Universitas Kristen Satya Wacana, Jalan Diponegoro No. 52-60, Salatiga. SMP Kristen Laboratorium Universitas Kristen Satya Wacana, Jalan Diponegoro No. 52-60, Salatiga.

A R T I C L E I N F O

Article history:

Received 17-18-2020

Revised 18-18-2020

Accepted 14-12-2020

Key words:

learning concentration; classical guidance; jigsaw type cooperative learning

\begin{abstract}
A B S T R A C T
Students should have the ability to concentrate during the learning process so that they are able to follow the learning process and achieve the expected learning objectives. Classical guidance services through the Jigsaw type cooperative learning method aims to increase concentration in following lessons. Participants in this activity were 21 students of class VIII-A of the Satya Wacana Christian Middle School in Salatiga. Service activities are carried out in three stages: the initial stage, the core stage, and the closing stage. Based on the analysis, it was found that 15 people got a Very High score (71\%), 5 people got a High score (24\%), and 1 person got a moderate score $(1 \%)$. It can be concluded that the Classical Guidance Service activities through the Jigsaw Cooperative Learning method can increase the learning concentration of class VIII-A students of Satya Wacana Christian Middle School in Salatiga.
\end{abstract}

\begin{abstract}
A B S T R A K
Peserta didik hendaknya memiliki kemampuan konsentrasi saat proses belajar berlangsung sehingga mampu mengikuti proses belajar dan mencapai tujuan pembelajaran yang diharapkan. Layanan bimbingan klasikal melalui metode cooperative learningtipe Jigsaw bertujuan untuk meningkatkan konsentrasi dalam mengikuti pelajaran. Partisipan dalam kegiatan ini adalah peserta didik kelas VIII-A SMP Kristen Satya Wacana Salatiga dengan jumlah 21 orang. Kegiatan layanan dilakukan melalui tiga tahap yakni: tahap awal, tahap inti, dan tahap penutup. Jumlah partisipan 15 orang dan mendapatkan skor Sangat Tinggi (71\%),
\end{abstract}


5 orang mendapatkan skor Tinggi (24\%), dan 1 orang yang mendapatkan skor sedang (1\%). Dapat disimpulkan bahwa kegiatan Layanan Bimbingan Klasikal melalui metode Cooperative Learning tipe Jigsaw dapat meningkatkan konsentrasi belajar peserta didik kelas VIII-A SMP Kristen Satya Wacana Salatiga.

\section{PENDAHULUAN}

Pendidikan di negara Indonesia memiliki fungsi untuk mengembangkan kemampuan dan membentuk watak serta peradaban bangsa yang bermartabat dalam rangka mencerdaskan kehidupan bangsa, bertujuan untuk berkembangnya potensi peserta didik agar menjadi manusia yang beriman dan bertakwa kepada Tuhan Yang Maha Esa, berakhlak mulia, sehat, berilmu, cakap, kreatif, mandiri, dan menjadi warga negara yang demokratis serta bertanggung jawab (Undang-undang Republik Indonesia No 20 tahun 2003 tentang Sistem Pendidikan Nasional). Pemerintah dan masyarakat terus berupaya untuk meningkatkan kualitas pendidikan di Indonesia. Hal ini terwujud melalui pemberian sertifikasi bagi guru, mengembangkan kurikulum yang sesuai perkembangan jaman dan kebutuhan di masyarakat, mengembangkan metode dan media pembelajaran bagi peserta didik hingga memberikan bantuan operasional sekolah (BOS) yang mendukung pengembangan sarana dan prasarana sekolah sehingga harapannya peserta didik semakin merasa nyaman belajar, konsentrasi belajar meningkat dan pada akhirnya kuantitas dan kualitas belajar dapat dioptimalkan.

Peserta didik hendaknya memiliki kemampuan berkonsentrasi saat proses belajar berlangsung. Melalui konsentrasi belajar, peserta didik mampu untuk mengikuti proses belajar sehingga mampu mencapai tujuan pembelajaran yang diharapkan. Konsentrasi diperlukan dalam proses membaca, mendengar, maupun menulis. Pada usia sekolah, prestasi belajar seorang siswa sangat dipengaruhi oleh kemampuan menyerap pelajaran yang diberikan. Kemampuan memahami materi pelajaran diperoleh karena memperhatikan apa yang diajarkan guru maupun dari hasil upaya belajar mandiri, ditentukan oleh kemampuan konsentrasi (Mulyana et al., 2013).

Konsentrasi adalah usaha untuk memusatkan perhatian terhadap objek yang dibutuhkan dengan mengabaikan stimulus lain yang tidak diperlukan (Sukri \& Purwanti, 2016). Terdapat faktor internal dan faktor eksternal yang memengaruhi konsentrasi, Adapun faktor internal misalnya: keadaan jasmani dan rohani yang sehat, tidak ada gangguan di dalam panca indera, tubuh dalam kondisi fit, tidak sedang dalam keadaan stress atau tertekan, dan memiliki ketenangan batin dan emosi. Sedangkan faktor ekternal misalnya: suasana lingkungan yang tenang, terbebas dari polusi udara, penerangan cukup, dan sarana prasarana yang memadai (Ikawati, 2015). Secara khusus, di dalam kegiatan ini, akan fokus pada konsentrasi pada proses belajar atau sering disebut konsentrasi belajar.

Konsentrasi belajar adalah kemampuan untuk mengarahkan segala pikiran dan perbuatan sehingga mampu mempelajari suatu hal dengan baik. Pada saat mempelajari materi di kelas, peserta didik seringkali mengalami berbagai macam gangguan (noise) yang berasal dari dalam dan luar diri sehingga dapat mengganggu konsentrasi belajar. Pada saat belajar, kadang kala tanpa disadari muncul pikiran mengenai masalahmasalah lama dan keinginan lain menjadi pengganggu aktivitas belajar kita. Suasana 
belajar dimana kelas penuh, cuaca panas, suara bising dari luar ruangan juga seringkali membuat siswa mengalami gangguan sehingga sulit untuk berkonsentrasi. Gangguan konsentrasi belajar banyak dialami peserta didik terutama saat mempelajari mata pelajaran yang mempunyai tingkat kesulitan tinggi. Kesulitan menjaga konsentrasi belajar juga semakin bertambah jika peserta didik terpaksa mempelajari materi pelajaran yang tidak disukainya (Ikawati, 2015).

Peserta didik yang dapat mengelola konsentrasi belajarnya akan menjadikannya mampu memahami dan mengaplikasikan segala informasi yang didapatkan. Dengan pemahaman tentang materi pelajaran yang disampaikan guru, maka peserta didik akan mendapat nilai yang tinggi di kelas. Sedangkan peserta didik yang tidak dapat menjaga konsentrasi ketika sedang belajar maka akan mengalami kesulitan dalam melakukan aktivitas belajar secara menyeluruh, dan dapat berdampak pada hasil belajar yang kurang optimal. Kesulitan konsentrasi yang dialami disebabkan karena peserta didik tidak dapat memperhatikan penjelasan guru dengan baik, kesulitan menerima materi pelajaran yang diberikan guru, serta kesulitan menjawab pertanyaan yang diberikan guru secara langsung maupun mengerjakan soal-soal materi pelajaran yang diberikan oleh guru. Apabila kondisi peserta didik tidak mampu memaksimalkan konsentrasi belajar terus dibiarkan, maka dampaknya pada nilai dan hasil pembelajaran yang tidak maksimal (Mindari \& Supriyo, 2015).

Siswa yang tidak dapat memfokuskan pikiran terhadap materi pembelajaran disebabkan oleh beberapa hal misalnya: guru yang mengajar dengan metode pembelajaran klasikal atau kelompok menyebabkan siswa dianggap memiliki kemampuan berpikir yang sama; kurangnya keterampilan guru di dalam mengelola kelas sehingga metode pembelajaran yang diberikan bersifat monoton dan kurang bervariasi sehingga menyebabkan siswa menjadi pasif dan hanya mengandalkan guru; dan ditambah suasana di kelas yang panas, sesak, dan terkadang bising yang memunculkan gangguan suara sehingga suasana di kelas menjadi sangat tidak nyaman dan kondusif untuk belajar (Aviana \& Hidayah, 2015).

Hasil temuan di lapangan menunjukkan fenomena bahwa setelah dilakukan wawancara dengan guru Bimbingan dan Konseling (BK) di SMP Kristen Satya Wacana Salatiga, kondisi peserta didik dapat dikatakan belum memiliki kemampuan konsentrasi belajar di kelas. Hal ini ditunjukkan dari beberapa perilaku misalnya peserta didik ada yang melamun saat diberikan materi pelajaran, tidak memperhatikan guru yang berada di depan, dan beberapa ada yang mengobrol dengan teman sebangkunya. Dalam proses pembelajaran interaksi antara guru dan siswa kurang lancar dan lebih buruk lagi interaksi antara siswa dengan siswa hampir tidak terjadi dan hal ini membuat siswa tidak termotivasi untuk belajar.

Model pembelajaran konvensional merupakan tipe pembelajaran individu yang sedehana dimana siswa mengerjakan tugas mereka masing-masing sehingga kurang terjadi interaksi sosial dan lemahnya kemampuan siswa untuk bertukar informasi. Model pembelajaran konvensional merupakan model pembelajaran yang paling sering digunakan oleh guru dalam pembelajaran, sehingga hanya berpusat pada guru dan siswa terkadang tidak tertarik dalam pembelajaran tersebut (Irham et al., 2018).

Usaha untuk meningkatkan konsentrasi belajar siswa dapat dilakukan melalui bimbingan klasikal. Bimbingan klasikal atau bimbingan kelompok adalah jenis layanan yang ada pada konseling dengan menggunakan dinamika kelompok untuk 
membahas permasalahan yang dialami peserta didik. Melalui diskusi maka diharapkan peserta didik memperoleh pemahaman masalah sehingga mampu bertindak secara tepat. Pada bimbingan kelompok setiap anggota berhak mengemukakan pengalaman dan pendapatnya sehingga menambah wawasan anggota (Maiseptian et al., 2017). Selain itu, melalui bimbingan kelompok, siswa juga dapat mengurangi sikap negatif siswa seperti pemalu, suka memotong pembicaraan orang lain, dan perilaku tidak menghargai pendapat lain, serta menimbulkan sikap percaya, memahami, melatih kemampuan berkomunikasi, memecahkan konflik melalui cara konstruktif antar peserta didik (Erlangga, 2017). Secara khusus, metode diskusi yang digunakan yakni cooperative learning.

Pembelajaran dengan pendekatan kooperatif adalah pembelajaran yang dilakukan secara berkelompok. Peserta didik berkelompok kecil yang terdiri dari 4 orang untuk memahami konsep materi pelajaran yang akan dibimbing oleh guru. Dalam membentuk kelompok-kelompok kecil ini harus memperhatikan keberagaman anggota kelompok sebagai tempat bekerjasama dan memecahkan suatu masalah melalui interaksi sosial dengan teman sebayanya, memberikan kesempatan pada peserta didik untuk mempelajari sesuatu dengan baik pada waktu yang bersamaan dan ia menjadi narasumber bagi teman yang lain. Penerapan pembelajaran kooperatif akan memberikan hasil yang efektif kalau memperhatikan dua prinsip inti berikut. Yang pertama adalah adanya saling ketergantungan yang positif dan yang kedua adalah setiap anggota kelompok memiliki rasa tanggung jawab pribadi (individual accountability) untuk memiliki kontribusi aktif dalam bekerja sama (Sulikatin, 2017).

Cooperative learning memiliki berbagai macam jenis kegiatan, misalnya: Team Assisted Individualization (TAI), Talking Stick, Cooperative Integrated Reading Composition (CIRC), Jigsaw, dan berbagai jenis kegiatan lainnya. Dalam kegiatan ini dipilih jenis kegiatan cooperative learning tipe Jigsaw. Tipe Jigsaw, dimana teknik ini merupakan suatu pembelajaran yang berorientasi pada proses, membuat pembelajaran lebih bermakna dan meningkatkan pemahaman materi sehingga meningkatkan prestasi belajar dan kepercayaan diri siswa. Model pembelajaran kooperatif tipe Jigsaw, menekankan pembelajaran dalam kelompok kecil yakni sekitar empat sampai enam orang secara heterogen dan bekerja sama, bertanggungjawab secara mandiri, suasana gotong royong, dan mempunyai kesempatan untuk mengolah informasi dan meningkatkan ketrampilan berkomunikasi (Hijrihani \& Wutsqa, 2015).

Berdasarkan adanya kebutuhan tersebut, kegiatan pengabdian masyarakat ini dilakukan untuk meningkatkan konsentrasi belajar peserta didik melalui kegiatan pengabdian masyarakat yang berbasis layanan bimbingan klasikal dengan tujuan untuk meningkatkan konsentrasi belajar melalui layanan bimbingan kelompok dengan sasaran yaitu peserta didik kelas VIII-A di SMP Kristen Satya Wacana Salatiga. Adapun manfaat dari pengabdian masyarakat ini adalah peserta didik dapat mengembangkan konsentrasi dalam mengikuti pelajaran yang sedang dihadapi baik di rumah maupun di sekolah. 


\section{METODE PELAKSANAAN}

\section{Peserta dan Tema Kegiatan}

Kegiatan ini diawali dengan meminta ijin kepada Kepala Sekolah SMP Kristen Satya Wacana untuk melakukan kegiatan pengabdian masyarakat. Setelah mendapatkan ijin, peneliti menentukan hari dan jam untuk wawancara dengan salah satu Guru Bimbingan Konseling di (BK) SMP tersebut sebagai pengumpulan data awal dan pendukung untuk kegiatan ini. Wawancara dilakukan kepada Guru BK SMP Kristen Satya Wacana Salatiga sebagai narasumber. Narasumber menjelaskan peserta didik memiliki konsentrasi yang kurang baik, hal ini dikarenakan peserta didik ada yang melamun saat diberikan materi pelajaran, tidak memperhatikan guru yang berada di depan, dan beberapa ada yang mengobrol dengan teman sebangkunya. Akhirnya disepakati dengan Guru BK topik layanan yang diangkat yaitu konsentrasi belajar. Untuk partisipan dipilih secara random yakni kelas VIII-A yang berjumlah 21 orang. Rancangan Pelaksanaan Layanan (RPL) disusun, hari yang disepakati yakni Jumat tanggal 2 Agustus 2019. Secara lengkap, data disajikan pada Tabel 1.

Tabel 1. Rancangan Pelaksanaan Layanan

\begin{tabular}{ll}
\hline Indikator & Keterangan \\
\hline Tempat & SMP Kristen Satya Wacana Salatiga. \\
Topik Layanan & Konsentrasi Belajar \\
Peserta & Kelas VIII-A \\
Jumlah Peserta & 21 Peserta didik \\
Tanggal Pelaksanaan & 2 Agustus 2019 \\
Waktu Pelaksanaan & $08.00-12.00$ \\
\hline
\end{tabular}

\section{Prosedur Kegiatan}

Kegiatan ini dibagi tiga tahapan pelaksanaan yang meliputi tahapan awal atau pendahuluan, tahapan inti dan tahapan penutup. Tahapan disajikan secara lengkap dalam Tabel 2.

Tabel 2. Tahapan Kegiatan

\begin{tabular}{|c|c|c|}
\hline Tahapan Kegiatan & Tujuan & Rincian Kegiatan \\
\hline $\begin{array}{l}\text { Tahap Awal atau } \\
\text { Pendahuluan }\end{array}$ & $\begin{array}{l}\text { Menciptakan suasana } \\
\text { santai dan menjalin } \\
\text { keakraban di antara para } \\
\text { peserta didik. }\end{array}$ & $\begin{array}{l}\text { 1. Memberikan salam pembukaan dan } \\
\text { perkenalan. } \\
\text { 2. Menyampaikan Tujuan Umum dan } \\
\text { Tujuan Khusus kegiatan. } \\
\text { 3. Melakukan ice breaking. Ice breaking } \\
\text { berupa gerak jari-jari tangan diberikan } \\
\text { sebagai langkah awal melihat } \\
\text { konsentrasi mereka dalam mengikuti } \\
\text { kegiatan. }\end{array}$ \\
\hline Tahap Inti & $\begin{array}{l}\text { Meningkatkan } \\
\text { pemahaman tentang } \\
\text { konsentrasi belajar bagi } \\
\text { peserta didik. }\end{array}$ & $\begin{array}{l}\text { 1. Menyampaikan materi tentang definisi } \\
\text { Konsentrasi Belajar. } \\
\text { 2. Membagi Peserta didik ke dalam } \\
\text { kelompok (5-6 orang) untuk mencari } \\
\text { materi. Kelompok satu dengan topik } \\
\text { 'ciri-ciri konsentrasi belajar'; }\end{array}$ \\
\hline
\end{tabular}




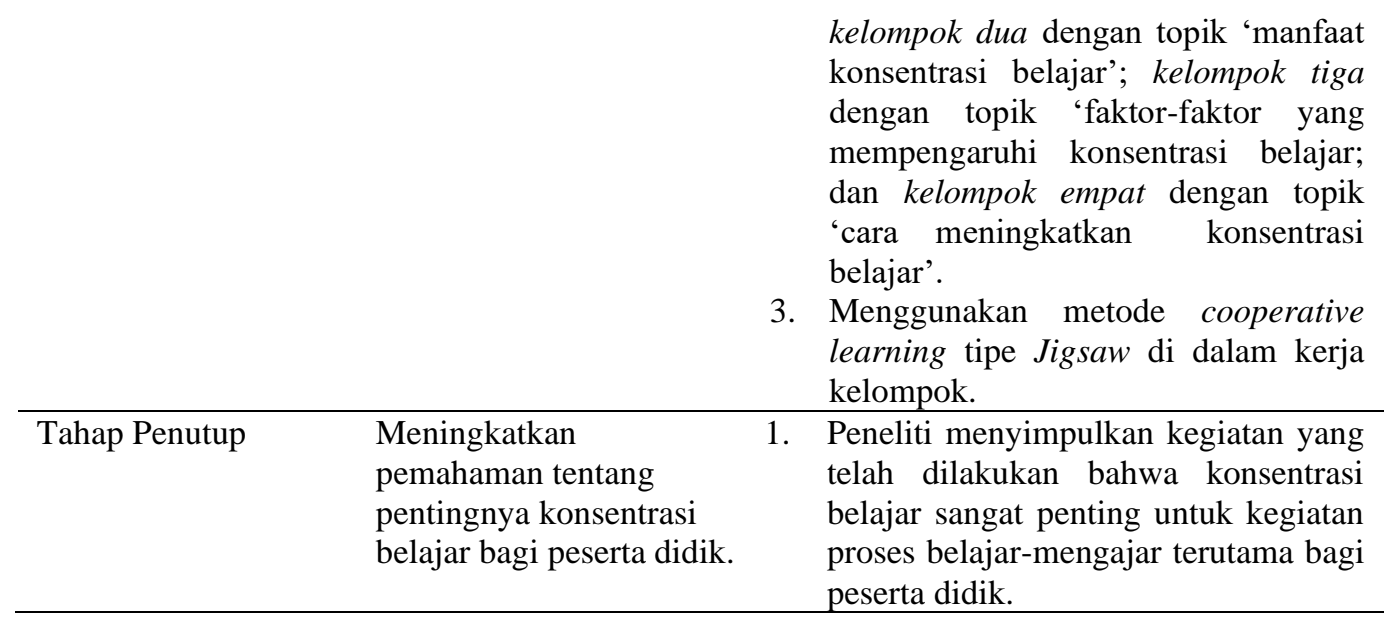

\section{HASIL DAN PEMBAHASAN}

Peneliti menggunakan analisis data deskriptif untuk mencari tingkat persentase konsentrasi belajar peserta didik berdasarkan skala konsentrasi belajar. Peneliti menggunakan analisis deskriptif yaitu dengan menjelaskan hasil perhitungan skor hasil Penilaian Segera (laiseg). Skala konsentrasi belajar menggunakan skor 0 sampai 2. Berdasarkan perhitungan di atas maka kriteria penilaian tingkat peningkatan konsentrasi belajar disajikan dalam Tabel 3.

Tabel 3. Kriteria Penilaian Tingkat Konsentrasi Belajar

\begin{tabular}{ll}
\hline \multicolumn{1}{c}{ Interval } & \multicolumn{1}{c}{ Kriteria } \\
\hline $68 \%-100 \%$ & Sangat Tinggi \\
$61 \%-67 \%$ & Tinggi \\
$54 \%-60 \%$ & Sedang \\
$47 \%-53 \%$ & Rendah \\
$40 \%-46 \%$ & Sangat Rendah \\
\hline
\end{tabular}

Kriteria penilaian tingkat konsentrasi belajar yang digunakan peneliti melalui interval perhitungan. Untuk kriteria peserta didik dari konsentrasi belajar Sangat Rendah mulai 40\% - 46\%, kriteria Rendah 47\% - 53\%, kriteria Sedang 54\% - 60\%, kriteria Tinggi $61 \%-67 \%$, dan untuk kriteria Sangat Tinggi 68\% - 100\%. 
Tabel 4. Kriteria Penilaian Tingkat Konsentrasi Belajar

\begin{tabular}{ccc}
\hline Responden & Skor & Kriteria \\
\hline A & 90 & Sangat Tinggi \\
B & 50 & Sedang \\
C & 60 & Tinggi \\
D & 90 & Sangat Tinggi \\
E & 70 & Sangat Tinggi \\
F & 60 & Tinggi \\
G & 60 & Tinggi \\
H & 80 & Sangat Tinggi \\
I & 60 & Tinggi \\
J & 90 & Sangat Tinggi \\
K & 60 & Tinggi \\
L & 80 & Sangat Tinggi \\
M & 80 & Sangat Tinggi \\
N & 80 & Sangat Tinggi \\
O & 70 & Sangat Tinggi \\
P & 70 & Sangat Tinggi \\
Q & 90 & Sangat Tinggi \\
R & 90 & Sangat Tinggi \\
S & 90 & Sangat Tinggi \\
T & 70 & Sangat Tinggi \\
U & 70 & Sangat Tinggi \\
\hline
\end{tabular}

Jika dilihat dari tingkat rata-rata peserta didik, mereka mempunyai nilai skor tingkat konsentrasi belajar sebesar 74,3 dengan persentase sebesar $74 \%$ yang masuk dalam kategori Sangat Tinggi.

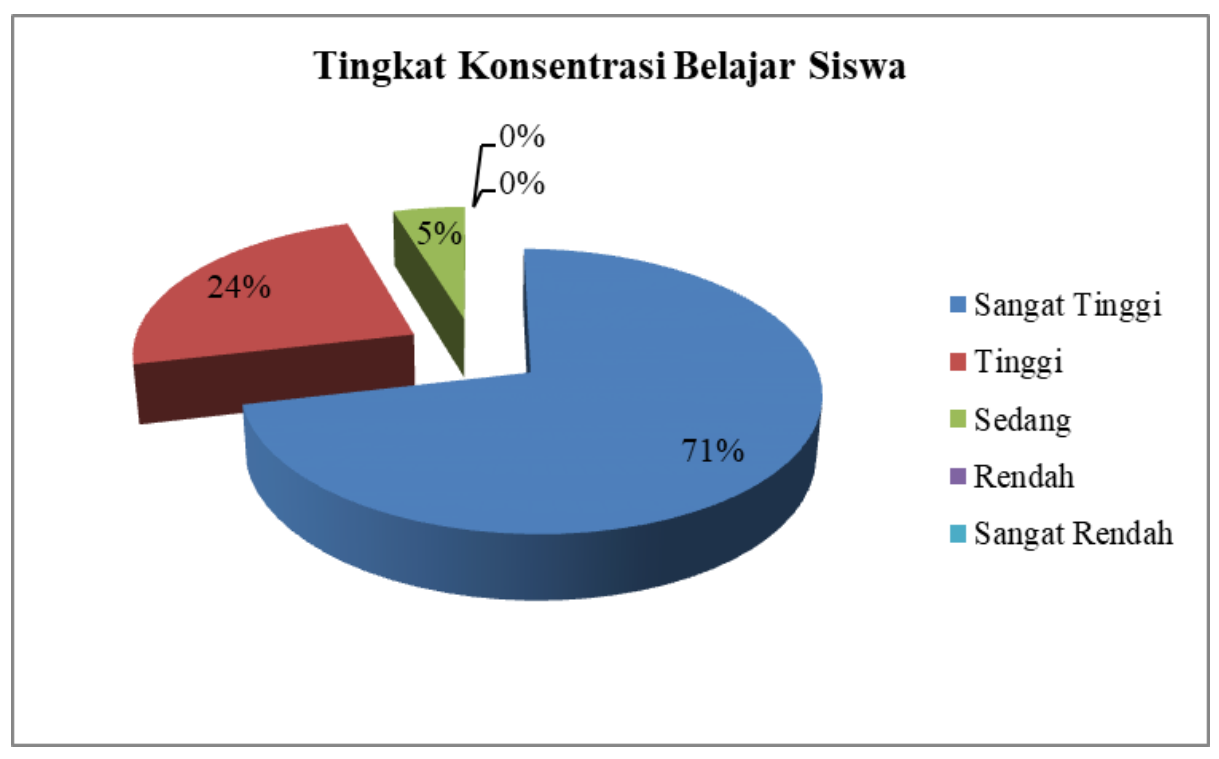

Gambar 1. Tingkat Konsentrasi Belajar Siswa

Berdasarkan Gambar 1, jumlah total peserta didik terdiri dari 21 orang, yang mana sejumlah 15 orang mendapatkan skor Sangat Tinggi (71\%). Peserta didik yang berjumlah 5 orang mendapatkan skor Tinggi (24\%), dan tersisa 1 orang yang 
mendapatkan skor sedang (1\%). Namun secara keseluruhan peserta didik menunjukkan tingkat konsentrasi yang Sangat Tinggi. Hal ini menunjukkan proses pemberian layanan secara klasikal melalui metode Jigsaw efektif dilakukan untuk meningkatkan konsentrasi peserta didik.

Pelaksanaan layanan melalui bimbingan klasikal ini didasari melalui metode Jigsaw yang digunakan dalam sebagai model pembelajaran kooperatif di kelas. Adapun pemillihan melalui metode ini sebagai bentuk dari cooperative learning adalah metode pembelajaran dalam kelompok yang tidak sama dengan belajar kelompok atau belajar bekerja sama biasa. Dalam kerja kelompok ini Peneliti membagi peserta didik dalam beberapa kelompok. Ada empat kelompok yang terdiri dari lima sampai enam orang. Di dalamnya peneliti memberikan topik berbeda pada masingmasing kelompok untuk berdiskusi dan menuangkan hasil diskusinya pada media yang disediakan yaitu kertas manila. Peserta didik dalam kelompoknya dapat menuangkan hasilnya pada media itu dengan kreativitas mereka yang akan digunakan untuk presentasi. Melalui metode Jigsaw, setiap peserta didik dituntut untuk bekerja dalam kelompok melalui rancangan-rancangan tertentu yang mereka persiapkan untuk menyampaikan hasil diskusinya agar membuat setiap peserta didik menjadi aktif dan konsentrasi melakukan proses diskusi.

Model pembelajaran kooperatif tipe Jigsaw sangat melibatkan aktivitas seluruh siswa, bertanggungjawab atas materinya masing- masing, karena seluruh siswa memiliki tugas masing-masing sehingga siswa lebih aktif dan tidak bosan dalam proses pembelajaran. Siswa dalam kelompoknya saling membantu dan bekerja sama untuk mencari tugas/ soal yang diberikan sehingga siswa yang kemampuan rendah juga bisa terbantu oleh siswa yang pintar. Model konvensional siswa hanya mendengarkan guru menjelaskan materi pelajaran, sehingga siswa bosan dan tidak aktif (Irham et al., 2018). Penerapan model pembelajaran kooperatif tipe Jigsaw memberikan kesempatan kepada siswa untuk mempelajari materi-materi yang diberikan dengan bekerja sama dalam kelompok. Mereka saling membantu satu sama lain dalam menghadapi masalah dan saling memberikan dorongan dan semangat untuk mencapai keberhasilan yang maksimal. Bekerja sama dengan teman dalam satu kelompok dapat meminimalkan rasa kurang percaya diri. Alasan yang mendasari hal tersebut adalah belajar dengan teman sebaya akan dapat menghilangkan rasa canggung, enggan, malu untuk bertanya ataupun meminta bantuan (Hijrihani \& Wutsqa, 2015)

Setiap peserta didik dituntut untuk bekerja dalam kelompok melalui rancangan tertentu yang sudah dipersiapkan untuk menyampaikan hasil diskusinya agar membuat setiap peserta didik menjadi aktif dan fokus untuk melakukan proses diskusi. Langkah tersebut diambil karena dengan menggunakan metode pembelajaran kooperatif, peserta didik akan termotivasi untuk dapat mengungkapkan ide di dalam wadah kelompok sendiri maupun kelompok lainnya. Pada akhirnya dari proses diskusi, konsentrasi peserta didik dapat menjadi lebih terlatih terhadap proses pembelajaran yang diterima sehingga memunculkan motivasi dan minat peserta didik untuk mengembangkan konsentrasi belajarnya terhadap materi atau bahan pelajaran.

Hasil kegiatan menunjukkan konsentrasi dalam berdiskusi membahas topik yang didapatkan sangat efektif dilakukan. Hal ini ditunjukkan dengan hasil karya peserta didik yang dituangkan melalui media kertas manila dan keaktifan saat berpendapat 
dalam kelompok. Setelah dari diskusi, masing-masing anggota kelompok menunjuk salah satu perwakilan untuk menyampaikan hasil diskusi di depan kelas. Ketika tahap inti akan berakhir, peneliti kembali menjelaskan topik yang dibahas masing-masing kelompok, agar semakin menambah pemahaman mereka untuk mengembangkan konsentrasi saat belajar ketika selesai dari kegiatan ini. Selanjutnya peneliti mengajak peserta didik untuk menyimak video dan menganalisa apa yang terjadi dari permasalahan tersebut. Beberapa peserta didik kemudian mengangkat tangan dan menjelaskan isi dari video tersebut yang dikaitkan ke semua topik kegiatan yang sudah dilakukan. Video yang diberikan memberikan pemahaman kepada peserta didik pentingnya konsentrasi saat belajar.

Ketika peserta didik bisa memusatkan perhatiannya dan mengabaikan stimulus dari luar peserta didik akan lebih mudah memahami materi atau bahan ajar yang dipelajar namun ketika peserta didik tidak bisa memusatkan perhatiaannya dan fokus dengan hal-hal lain, peserta didik pasti akan sulit untuk memahami materi yang dipelajar. Semuanya tergantung kepada peserta didik dengan melihat faktor-faktor yang ada dalam diri peserta didik, serta peserta didik perlu memiliki gaya belajar yang baik untuk membantu konsentrasi belajarnya. Setelah peneliti menyimpulkan kegiatan yang telah dilakukan, peneliti memberikan evaluasi ke peserta didik dengan harapan melihat sejauh mana proses kegiatan dari layanan yang diberikan apakah membantu peserta didik memahami dan mengembangkan konsentrasi belajarnya. Tentunya dari kegiatan ini, guru kembali memberikan motivasi dan penguatan kepada peserta didik untuk mendorong peserta didik mengembangkan konsentrasi dalam mengikuti pelajaran yang sedang dihadapi baik di rumah maupun di sekolah. Guru mengakhiri kegiatan dengan memberikan salam dan ucapan terima kasih kepada peserta didik dan foto bersama.

\section{KESIMPULAN}

Berdasarkan hasil kegiatan yang telah dilakukan menunjukkan sejumlah 15 orang peserta didik mendapatkan skor Sangat Tinggi (71\%), 5 orang mendapatkan skor Tinggi (24\%), dan 1 orang yang mendapatkan skor sedang (1\%). Maka dapat disimpulkan bahwa: Kegiatan Layanan Bimbingan Klasikal melalui metode Cooperative Learning tipe Jigsaw dapat meningkatkan konsentrasi belajar peserta didik kelas VIII-A SMP Kristen Satya Wacana Salatiga.

\section{UCAPAN TERIMA KASIH}

Peneliti mengucapkan terima kasih yang sebesar-besarnya kepada :

1. Pihak sekolah SMP Kristen Satya Wacana Salatiga yang memberikan kesempatan untuk mengijinkan pelaksanaan pengabdian masyarakat,

2. Ibu Asih Nuryani, S. Pd. selaku Guru BK SMP Kristen Satya Wacana Salatiga yang telah membantu memberikan saran, kritik dan motivasi demi berjalanannya pelaksanaan pengabdian masyarakat, serta

3. Seluruh peserta didik kelas VIII-A yang telah bekerja sama membantu dalam proses pelaksanaan pengabdian masyarakat di kelas. 


\section{DAFTAR PUSTAKA}

Aviana, R., \& Hidayah, F. (2015). Pengaruh Tingkat Konsentrasi Belajar Siswa Terhadap Daya Pemahaman Materi Pada Pembelajaran Kimia Di Sma Negeri 2 Batang. Jurnal Pendidikan Sains Universitas Muhammadiyah Semarang, 3(1), 30-33. https://doi.org/10.26714/jps.3.1.2015.30-33

Erlangga, E. (2017). Bimbingan Kelompok Meningkatkan Keterampilan Berkomunikasi Siswa. Psympathic : Jurnal Ilmiah Psikologi, 4(1), 149-156. https://doi.org/10.15575/psy.v4i1.1332

Hijrihani, C. P., \& Wutsqa, D. U. (2015). Keefektifan Cooperative Learning Tipe Jigsaw dan STAD Ditinjau dari Prestasi Belajar dan Kepercayaan Diri Siswa. Pythagoras: Jurnal Pendidikan Matematika, 10(1), 1-14. https://doi.org/10.21831/pg.v10i1.9091

Ikawati, M. P. D. (2015). Upaya Meningkatkan Konsentrasi Belajar Siswa KMS (Kartu Menuju Sejahtera) Menggunakan Konseling Kelompok Bagi Siswa. Psikopedagogia Jurnal Bimbingan Dan Konseling, 4(2), 158. https://doi.org/10.12928/psikopedagogia.v4i2.4484

Irham, I., Hala, Y., \& Ali, A. (2018). Pengaruh Model Pembelajaran Kooperatif Tipe Jigsaw terhadap Motivasi Belajar dan Hasil Belajar Biologi Siswa Kelas XI IPA SMA Negeri 18 Bulukumba. UNM Journal of Biological Education, 1(November 2017), 87-98.

Maiseptian, F., -, M., \& -, Y. (2017). Efektivitas Layanan Bimbingan Kelompok Dalam Meningkatkan Kecerdasan Emosional Siswa. Jurnal Penelitian Bimbingan Dan Konseling, 2(2), 1-8. https://doi.org/10.30870/jpbk.v2i2.3057

Mindari, T., \& Supriyo. (2015). Meningkatkan Konsentrasi Belajar Melalui Layanan Bimbingan Kelompok dengan Teknik Permainan. Indonesian Journal of Guidance and Counseling, 4(2), 65-71.

Mulyana, O. P., Izzati, U. A., \& Puspitadewi, N. W. S. (2013). Penerapan Relaksasi Atensi Untuk Meningkatkan Konsentrasi Belajar Pada Siswa Smk. Jurnal Psikologi Teori Dan Terapan, 3(2), 103. https://doi.org/10.26740/jptt.v3n2.p103-112

Sukri, A., \& Purwanti, E. (2016). Meningkatkan Hasil Belajar Siswa Melalui Brain Gym. Jurnal Edukasi Matematika Dan Sains, 1(1), 50. https://doi.org/10.25273/jems.v1i1.778

Sulikatin. (2017). Upaya Peningkatan Keaktifan Dan Hasil Belajar Ipa Materi Usaha Dan Energi Melalui Pembelajaran Dengan Pendekatan Kooperatif Bagi Siswa Kelas VIII.a Smp Negeri 4 Bae Kudus. Jurnal Profesi Keguruan, 3(1), 129133. 